\title{
Bahagia di Usia Tua : Sejahtera Fisik dan Psikologis
}

\author{
Missiliana Riasnugrahani ${ }^{1}$ \\ ${ }^{1}$ Fakultas Psikologi, Universitas Kristen Maranatha \\ Jl. Surya Sumantri no 65 Bandung \\ ${ }^{1}$ missiliana.ria@psy.maranatha.edu
}

\begin{abstract}
Abstrak - Keberhasilan pembangunan nasional dalam bidang kesehatan di Indonesia terlihat dari meningkatnya jumlah angka harapan hidup lansia. Meningkatnya harapan hidup ini harus diikuti dengan peningkatan kesejahteraan, tidak hanya secara fisik, namun juga psikis. Kesehatan fisik dan psikis memiliki kaitan yang erat, sehingga peningkatan keduanya harus dilakukan secara seimbang. Pada masa pandemi ini, kesejahteraan psikis harus semakin diperhatikan khususnya pada lansia, karena semakin banyaknya keterbatasan yang dirasakan lansia. Keterbatasan yang paling dirasakan adalah keterbatasan mobilisasi, harus tinggal di rumah, sehingga berpotensi menimbulkan rasa kesepian. Oleh karena itu kegiatan pengabdian ini bertujuan untuk memberikan pemahaman kepada para lansia di komunitas gereja tentang pentingnya kesehatan psikologis, serta cara-cara untuk meningkatkannya melalui kegiatan sehari-hari di rumah, khususnya dalam situasi pandemi. Kegiatan ini menggunakan pendekatan psikoedukasi berupa pemberian ceramah dan diskusi kelompok yang dilakukan secara daring selama 2,5 jam. Pada awal pertemuan lansia diajak untuk berdiskusi tentang mitos-mitos yang diyakini tentang lansia. Setelah itu disampaikan materi berupa fakta-fakta tentang lansia, sehingga lansia memahami mitos dan fakta tentang lansia. Lansia juga diajak berdiskusi tentang pengalaman dan cara mengatasi permasalahan yang muncul selama pandemi ini. Diskusi diarahkan untuk mengajarkan lansia cara meningkatkan kesejahteraan fisik dan psikologis selama pandemi. Evaluasi terhadap kegiatan ini menunjukkan bahwa setelah mengikuti kegiatan ini para lansia merasa lebih memahami pentingnya kesehatan fisik dan psikologis, serta semakin mengetahui cara-cara meningkatkannya dengan sederhana melalui kegiatan sehari-hari. Para lansia juga menemukan bahwa bersyukur adalah kunci utama untuk menemukan kebahagiaan di saat pandemi ini.
\end{abstract}

Kata kunci-bahagia, kesejahteraan, fisik, psikologis, psikoedukasi.

Abstract - The increasing life expectancy of the elderly showing the success of national development in the health sector in Indonesia. This increase in life expectancy must be in line with increases in well-being, both physically and psychologically. Physical and psychological health are closely related, so they need to be improved in a balanced way. During this pandemic, psychological well-being needs more attention given the increasing number of constraints experienced by the elderly. The limitation felt was mobility, which could potentially lead to feelings of loneliness. Therefore, this activity aims to provide an understanding to the elderly in the church community about the importance of psychological health, as well as ways to improve it through daily activities, especially in a pandemic situation. This activity uses a psychoeducational approach through lectures and group discussions conducted online for 2.5 hours. At first, there was a discussion about the myths and facts believed about the elderly. With this activity, the elderly become aware of the myths and facts about the elderly. The elderly also discuss their experiences and how to overcome problems that arose during this pandemic. Discussions are guided to teach the elderly how to improve their physical and psychological well-being during the pandemic. After participating in this activity, the elderly feel more aware of the importance of physical and psychological well-being, and how to improve it only through daily activities. The elderly find that gratitude is the essential key to finding happiness during this pandemic.

Keywords-happiness, well-being, physical, psychological, psychoeducational.

\section{PENDAhUluan}

Indonesia merupakan salah satu negara yang diperkirakan akan masuk pada kelompok negara dengan populasi menua (ageing society). Negara dikatakan berada di kelompok populasi menua jika jumlah populasi di atas usia 60 tahun lebih dari 10 persen dari total penduduknya. Berdasarkan sensus penduduk tahun 2020, jumlah penduduk lanjut usia (lansia) Indonesia mencapai 9,78 persen dari total penduduk [1]. Jika melihat trend peningkatan dari tahun ke tahun, maka hampir dapat dipastikan Indonesia akan memasuki populasi menua.

Banyaknya populasi lansia perlu mendapatkan perhatian dari negara untuk mulai memikirkan strategi meningkatkan 
pelayanan kepada para lansia. Jika lansia memiliki kesehatan, pendidikan dan keterampilan yang memadai, maka struktur penduduk ini justru akan mendatangkan bonus demografi bagi Indonesia [2]. Meskipun demikian tugas untuk meningkatkan pelayanan kesehatan dan kesejahteraan lansia bukan hanya tugas pemerintah, tapi juga tugas masyarakat [3]. Masyarakat diharapkan dapat mendampingi kelompok ini untuk meningkatkan kesejahteraan fisik dan psikologisnya.

Kesejahteraan fisik dan psikologis lansia perlu mendapat perhatian khusus terutama dalam situasi pandemi Covid-19. Kelompok lansia menjadi semakin rentan dalam situasi pandemi, karena kelompok lansia mengalami dampak langsung dan tidak langsung dari pandemi. Lansia yang sebagian besar memiliki penyakit penyerta (comorbid) akan lebih rentan terhadap penyebaran virus Covid-19, dan mereka juga merasakan dampak tidak langsung terkait kebijakan penanganan penyebaran virus, seperti kebijakan Pembatasan Sosial Berskala Besar (PSBB) ataupun Pemberlakuan Pembatasan Kegiatan Masyarakat (PPKM).

Menurut hasil penelitian Tim Nasional Percepatan Penangulangan Kemiskinan (TNP2K), kelompok lansia memiliki kerentanan yang lebih besar dibandingkan kelompok usia lainnya, yaitu dalam hal sosial dan ekonomi. Berdasarkan hasil survey TNP2K pada tahun 2020 ditemukan beberapa dampak Covid-19 pada lansia, yaitu (1) mobilitas lansia menjadi lebih terbatas sehingga memengaruhi kemudahan askes pada layanan dasar termasuk layanan kesehatan, (2) sebanyak $80 \%$ lansia tidak memiliki akses ke bantuan pendapatan minimum/tunjangan pensiun sehingga rentan mengalami guncangan ekonomi, (3) lansia memiliki potensi lebih besar mengalami gangguan kesejahteraan psikologis seperti depresi, kecemasan dan perasaan tidak berdaya [4].

Meskipun demikian, survey pada beberapa daerah di Indonesia menunjukkan bahwa kelompok lansia tidak mengalami stress yang lebih besar dibandingkan kelompok usia lainnya, bahkan pada usia yang lebih tua, cenderung tidak ada peningkatan gangguan psikologis selama pandemi dibandingkan sebelum pandemi covid-19 [5]. Ditemukan pula di daerah tertentu di Indonesia, lansia merasa lebih meningkat harapannya, karena lebih dibutuhkan dan memiliki peran penting dalam keluarga [6]. Berdasarkan hasil survey, diketahui pula bahwa cara atau respon para lansia menghadapi kondisi pandemi berbeda dengan kelompok usia lainnya. Lansia berusaha menjaga kesehatan fisik dengan menerapkan gaya hidup sehat dan menjaga kesehatan psikis dengan banyak melakukan kegiatan ibadah [6].

Berdasarkan hasil survey tersebut, maka dapat dikatakan bahwa terjadinya gangguan kesehatan fisik dan psikis lansia dipengaruhi oleh faktor internal lansia, yaitu keyakinan (belief) atau cara pandang lansia dalam melihat situasi pandemi. Keyakinan ini akan memengaruhi sikap dan cara lansia berespon pada situasi yang sulit. Menurut Connors dan Halligan [7], keyakinan adalah sesuatu yang diyakini benar dan menjadi panduan dalam memahami dunia dan bertindak di dalamnya. Keyakinan menjadi dasar bagi individu untuk menilai lingkungan, menafsirkan pengalaman baru dan mengkonstruksi makna tentang sesuatu. Keyakinan menyediakan kerangka tujuan dan panduan tingkah laku [7]. Keyakinan memengaruhi cara individu menangani kejadian hidup yang negatif [8], dan keyakinan yang keliru akan mengarah pada emosi dan perilaku yang salah pula [7]. Keyakinan (belief) individu diketahui dapat memiliki kaitan yang erat dengan kesejahteraan psikologis individu [9].

Oleh karena itu untuk meningkatkan kesejahteraan fisik dan psikologis lansia, harus dimulai dari pemberian pemahaman yang benar tentang keadaan dan kemampuan dirinya. Lansia sebaiknya memiliki pandangan dan pemahaman yang benar tentang diri, dan hal-hal yang dapat dilakukan untuk mengatasi masalah yang mungkin muncul dari situasi pandemi. Lansia juga harus diberikan pemahaman tentang pentingnya menjaga kesehatan psikologis yang seringkali diabaikan dan tidak ditangani dengan sungguh-sungguh. Pemahaman yang benar diharapkan akan menimbulkan keyakinan yang baru tentang kondisi dan potensi diri yang dimiliki, sehingga dapat melakukan upaya penanganan secara mandiri masalah yang ditemui dalam situasi pandemi.

Upaya pemberian pemahaman ini akan dilakukan melalui pendekatan psikoedukasi. Psikoedukasi adalah pendidikan publik yaitu memberikan informasi pada masyarakat luas tentang berbagai pengetahuan dan keterampilan untuk mengatasi permasalahan sehari-hari [10]. Psikoedukasi mengabungkan elemen cognitive-behavior therapy, group therapy dan pendidikan. Tujuan dari psikoedukasi adalah memberikan pengetahuan pada individu tentang kondisi psikologis individu dan cara penanganannya [11]. Psikoedukasi menjadi teknik intervensi paling tepat karena memiliki beberapa karakteristik yang sesuai dengan tujuan kegiatan, yaitu memberikan pengajaran dan pendidikan, memiliki kegiatan yang terencana dan terstruktur, fokus pada pencegahan, tidak melakukan seleksi peserta, dapat berbentuk kelompok yang besar, dan jumlah sesi dapat hanya sekali saja [12]. Selain itu, teknik psikoedukasi sudah terbukti efektif untuk meningkatkan pengetahuan dan pemahaman para lansia tentang cara beradaptasi dengan kebiasaan baru di masa pandemi [13]. Dalam kegiatan ini digunakan metode ceramah dan diskusi kelompok yang dilakukan secara daring selama 2,5 jam.

Intervensi dengan pendekatan psikoedukasi bertemakan Bahagia dan Ceria di Usia Senja bertujuan untuk 
memberikan pemahaman tentang cara untuk meningkatkan kesejahteraan fisik dan psikologis pada lansia, yang meliputi pengetahuan tentang mitos dan fakta tentang lansia, serta cara mengatasi permasalahan yang muncul selama pandemi ini. Diskusi diarahkan untuk memberikan pengetahuan pada lansia tentang cara meningkatkan kesejahteraan fisik dan psikologis selama pandemi. Efektivitas intervensi akan dievaluasi berdasarkan dua level evaluasi pelatihan yaitu level reaksi atau kepuasan peserta, dan level pembelajaran yaitu adanya perubahan pengetahuan sebagai hasil dari intervensi [14].

\section{Metode Penelitian}

Intervensi ini menggunakan metode kuantitatif untuk mengetahui perubahan pengetahuan dan pemahaman peserta sebelum dan sesudah intervensi. Selain itu akan dilakukan pula pengolahan data statistik secara deskriptif untuk mengetahui evaluasi peserta terhadap materi, pemateri dan penyelengaaran kegiatan. Melalui teknik purposive sampling, diperoleh 25 lansia yang tergabung dalam komunitas lansia gereja.

Alat ukur yang digunakan untuk mengukur pemahaman dan evaluasi peserta adalah kuesioner yang disusun oleh penulis. Kuesioner berisi 5 pertanyaan tentang materi untuk mengukur level pembelajaran. Untuk mengukur level reaksi terdapat empat pertanyaan evaluasi tentang pemahaman materi dan kegunaan materi, serta 4 pertanyaan evaluasi tentang penyelengaraan intervensi. Setiap pertanyaan disediakan pilihan jawaban dan peserta cukup memilih jawaban yang dirasakan benar atau paling sesuai dengan dirinya. Untuk pertanyaan level pembelajaran, yaitu pemahaman materi, diberikan 2 pilihan jawaban yaitu "mitos" dan "fakta", sedangkan untuk pertanyaan level reaksi diberikan 4 pilihan jawaban bergradasi mulai dari (1) kurang sesuai/kurang baik sampai (4) sangat sesuai/sangat baik.

Kuesioner diberikan sebelum dan sesudah pemberian materi. Kuesioner dibuat singkat dan dilakukan melalui aplikasi polling dalam perangkat zoom meeting. Metode pengambilan data ini dilakukan mengingat keterbatasan lansia dalam mengisi kuesioner secara daring. Metode pengambilan data dengan cara polling berdampak pada jenis data yang diperoleh. Data mengenai pemahaman isi materi (level pembelajaran) berupa data kelompok, yang menunjukkan jumlah peserta yang menjawab benar untuk setiap pertanyaan.

Untuk mengetahui adanya perbedaan jumlah peserta yang menjawab dengan benar di setiap pernyataannya antara pretest dan posttest digunakan uji statistik non parametrik Wilcoxon Signed Rank Test. Perbedaan jumlah peserta yang menjawab benar menggambarkan meningkatnya pemahaman kelompok dalam setiap pertanyaan yang diberikan. Sementara itu, data mengenai evaluasi materi dan penyelengaraan kegiatan (level reaksi) dianalisis secara deskriptif, berupa persentase yang menggambarkan frekuensi pilihan peserta terhadap setiap pilihan jawaban.

\section{HASIL}

Tabel I menunjukkan jumlah peserta yang menjawab benar pada 5 pertanyaan terkait materi yang diberikan. Hasil menunjukkan bahwa secara umum terjadi perubahan pengetahuan dan pemahaman pada kelompok terkait materi yang diberikan, yang terlihat dari meningkatnya jumlah peserta yang menjawab benar.

TABEL I

HASIL PENGISIAN KUESIONER

\begin{tabular}{|c|c|c|}
\hline \multirow{2}{*}{ Pertanyaan } & Pre-test & Post-test \\
\cline { 2 - 3 } & $\mathrm{N}$ & $\mathrm{N}$ \\
\hline 1 & 0 & 25 \\
\hline 2 & 18 & 25 \\
\hline 3 & 10 & 25 \\
\hline 4 & 5 & 25 \\
\hline 5 & 10 & 25 \\
\hline
\end{tabular}

Tabel II menunjukkan hasil evaluasi level pembelajaran dengan teknik analisis uji non parametrik Wilcoxon Signed Rank Test. Terlihat nilai signifikansi Asym.sig (2-tailed) < 0,05 , yang berarti terdapat perbedaan pengetahuan sebelum dan sesudah diberikan psikoedukasi. Peserta mendapat pemahaman baru tentang pemikiran yang benar dan salah mengenai kondisi lansia. Pengetahuan ini dapat menjadi keyakinan baru, khususnya setelah peserta diberikan berbagai macam data dan fakta terkait hal-hal yang selama ini diyakininya. Peserta juga mendapatkan pemahaman tentang kaitan keyakinan dengan perilaku yang ditampilkan saat mengatasi masalah.

TABEL II

HASIL UJI BEDA

\begin{tabular}{|c|c|c|}
\hline Variabel & & Post-Pre \\
\hline \multirow{2}{*}{$\begin{array}{c}\text { Pemahaman } \\
\text { materi }\end{array}$} & $\mathrm{Z}$ & $-2,032$ \\
\cline { 2 - 3 } & $\begin{array}{c}\text { Asym.Sig (2- } \\
\text { tailed) }\end{array}$ & 0,042 \\
\hline
\end{tabular}

Berdasarkan observasi, juga terlihat bahwa peserta tampak menyadari bahwa pemikirannya selama ini adalah mitos, dan hal ini memengaruhi perilaku yang ditampilkan saat menghadapi masalah. Peserta juga tampak antusias ketika diberikan waktu untuk berdiskusi, mereka menyampaikan apa yang dipikirkan, dan mendiskusikan apakah pemikiran mereka itu salah atau benar, mitos atau fakta. Peserta lain selalu menanggapi setiap pertanyaan yang diajukan, baik dalam bentuk pernyataan kesetujuankarena memiliki pengalaman yang sama-atau memberikan pandangan lain tentang pemikiran tersebut. Diskusi menumbuhkan pemahaman baru tentang pentingnya memiliki pengetahuan dan keyakinan yang benar, karena 
keyakinan yang benar akan memengaruhi cara mereka mengatasi masalah, termasuk memilih alternatif pemecahan masalah.

Hal ini sejalan dengan Brown [15] yang mengungkapkan bahwa komponen utama dari psikoedukasi adalah berpikir dan kognisi, serta bertujuan untuk meningkatkan refleksi diri, kesadaran diri, pengetahuan dan pemahaman diri. Oleh karena itu pendekatan psikoedukasi menjadi efektif untuk memberikan pengetahuan dan pemahaman baru untuk mengubah keyakinan yang keliru. Selain itu proses diskusi yang dilakukan menjadi sangat membantu peserta untuk mengenali dan memahami diri tentang keyakinan dan cara pandangnya selama ini.

Dalam pemberian materi, juga diberikan materi berupa video bertema motivasi yang menunjukkan tentang bagaimana kaitan usia, kekuatan mental dan kekuatan fisik pada seekor gajah kerajaan. Melalui video ini diberikan pesan motivasi berupa ulasan bahwa usia tidak selalu membatasi kemampuan seseorang, tapi keyakinan dan cara pikirlah yang membuat orang merasa mampu atau tidak mampu melakukan sesuatu. Berdasarkan hasil observasi, penanyangan video mempermudah peserta menangkap pesan yang disampaikan pembicara, sehingga peserta dapat mengungkapkan pesan implisit yang ada di dalam video. Hal ini sejalan dengan penelitian Hébert, Dagenais, Mc Sween-Cadieux, dan Ridde [16], yang menunjukkan bahwa video adalah alat transfer pengetahuan dan juga alat training yang efektif bagi para profesional kesehatan. Video dapat menjadi alat pendidikan yang sangat efektif karena dirasakan lebih menarik dan cocok untuk menerangkan fenomena abstrak atau yang sulit divisualisasikan [17]. Oleh karena itu metode visualisasi dengan video membantu para peserta untuk mengenali secara konkrit pesan implisit dalam tayangan bahwa kesehatan fisik sangat terkait dengan kesehatan psikologis, dan cara paling penting untuk meningkatkannya adalah melalui cara tetap bersemangat dan bersyukur.

Setelah pertanyaan pada level pembelajaran, peserta juga diminta memberikan evaluasi pada level reaksi, yaitu tentang kemenarikan dan kebermanfaatan materi (gambar $1)$.

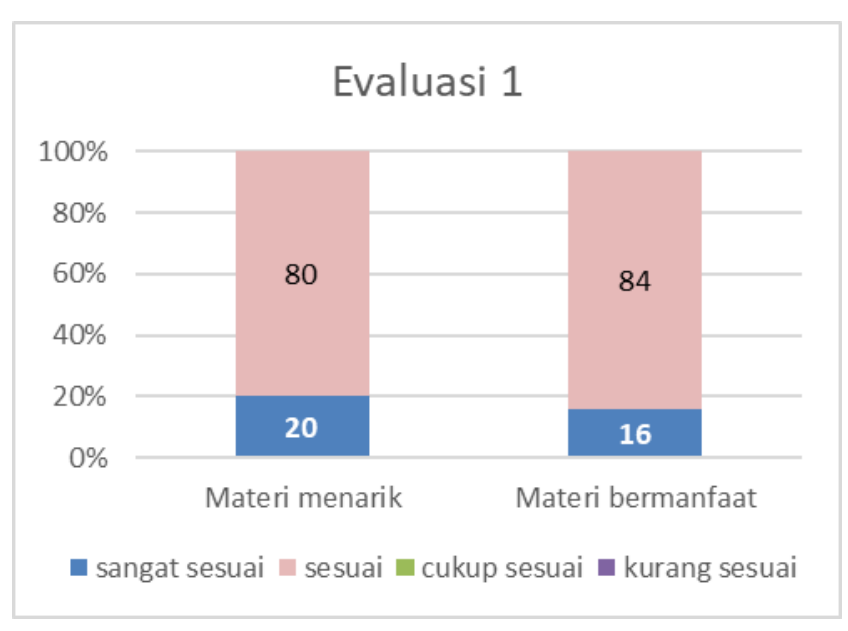

Gambar 1. Hasil evaluasi peserta terhadap kemenarikan dan kebermanfaatan materi.

Peserta merasakan kepuasan karena materi dianggap menarik dan bermanfaat. Dari hasil observasi juga terlihat bahwa peserta mengungkapkan ketertarikannya pada materi karena dianggap sesuai dengan kebutuhannya saat ini. Peserta juga tampak aktif berdiskusi untuk memperdalam dan mengeksplorasi materi dengan membahas berbagai pengalaman sehari-hari selama pandemic Covid-19.

Selanjutnya peserta juga melakukan evaluasi pada level reaksi terkait pemahaman materi. Peserta juga merasa memahami materi dan tergugah menerapkannya dalam kehidupan sehari-hari (gambar 2). Penghayatan peserta bahwa dirinya memahami materi sejalan dengan hasil uji beda (tabel II), yang menunjukkan adanya peningkatan pengetahuan dan pemahaman peserta antara sebelum dan setelah intervensi. Hal ini berarti baik secara objektif maupun subjektif, pemahaman peserta akan materi ditemukan meningkat. Psikoedukasi dapat disimpulkan merupakan teknik intervensi yang efekif untuk meningkatkan pengetahuan dan pemahaman peserta. Hal ini sejalan dengan penelitian Buizza et al. [18] yang menunjukkan bahwa psikoedukasi yang diberikan secara berkelompok terbukti efektif meningkatkan kesehatan mental dari pesertanya. 


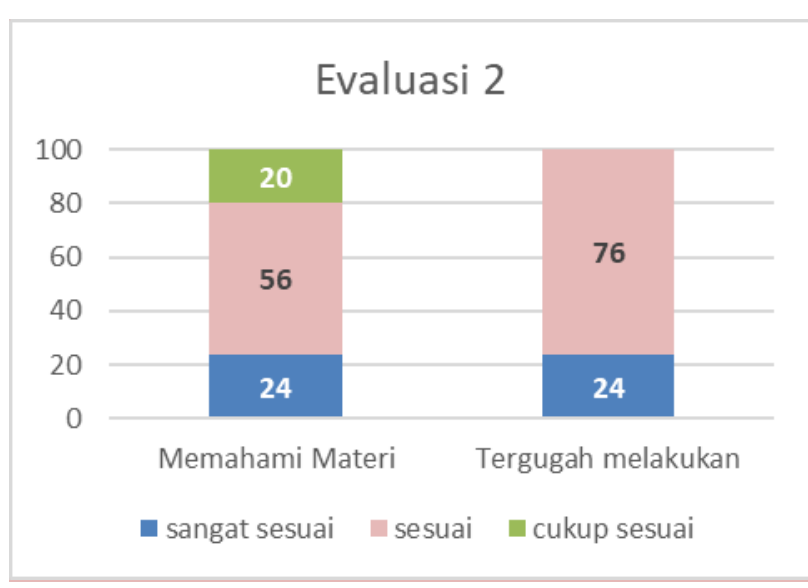

Gambar 2. Hasil evaluasi peserta terhadap pemahaman dan ketergugahan materi.

Selanjutnya peserta juga melakukan evaluasi pada level reaksi terhadap penyelengaraan intervensi. Penilaian reaksi penting dilakukan untuk mengetahui reaksi peserta terhadap pelaksanaan kegiatan. Reaksi positif terhadap kegiatan dapat meningkatkan motivasi peserta untuk mengikuti pelatihan, dan menerapkan pengetahuan yang diperoleh. Pelatihan dapat berjalan efektif jika peserta memiliki reaksi yang positif terhadap pelatihan [14]. Hasil penilaian dapat dilihat pada gambar 3 .

Hasil menunjukkan bahwa peserta menganggap pelaksanaan kegiatan sudah baik, bahkan sangat baik, baik dari durasi kegiatan, durasi diskusi, penguasaan materi dan peralatan penunjang (gambar 3). Maka dapat disimpulkan bahwa pada level reaksi, peserta merasakan kepuasan terhadap penyelenggaraan kegiatan baik dari sisi pemateri, jadwal dan waktu. Berdasarkan observasi juga terlihat bahwa peserta tetap berespon positif sampai akhir pemberian materi, dan menunjukkan ketertarikan mengetahui setiap materi yang diberikan. Peserta juga tampak bersemangat saat sesi diskusi dimulai, bahkan beberapa pertanyaan terus berlanjut sampai seluruh peserta menyatakan pendapatnya. Semua peserta tampak aktif bertanya dan memberikan pendapat pada pertanyaan peserta lainnya.

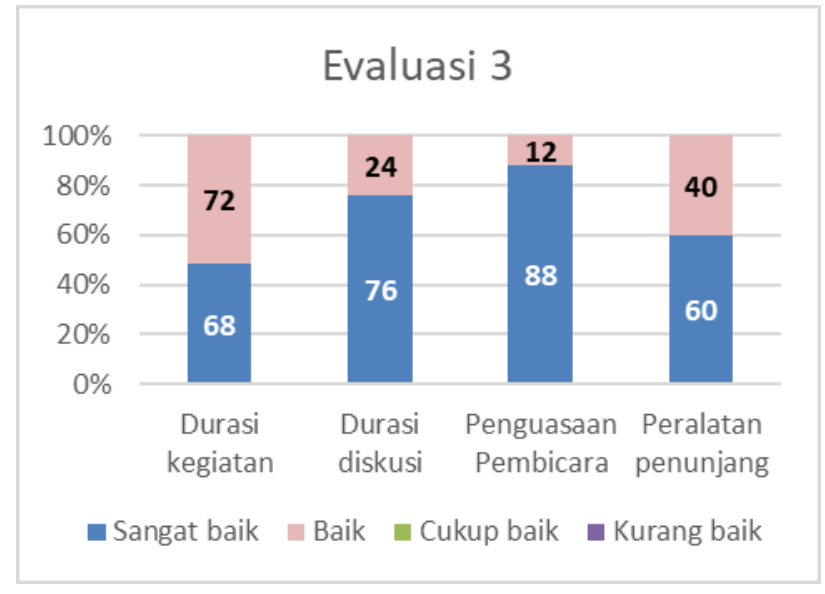

Gambar 3. Hasil evaluasi peserta terhadap penyelengaraan kegiatan.

Penilaian reaksi menjadi hal penting yang dievaluasi pada kegiatan ini, karena evaluasi ini juga bermanfaat bagi penyelenggara kegiatan sebagai pertimbangan mengurangi atau menghilangkan program, mengetahui efektivitas program dan bagaimana program itu dapat ditingkatkan. Hasil penilaian ini akan menjadi informasi kuantitatif untuk mengetahui keinginan dan kebutuhan peserta serta untuk perbaikan program nantinya [14].

\section{KESIMPULAN}

Pendekatan psikoedukasi mampu memberikan pemahaman dan keyakinan baru bagi para lansia tentang pentingnya kesehatan psikologis, serta cara-cara untuk meningkatkannya melalui kegiatan sehari-hari di rumah. Lansia dapat mengenali keyakinan keliru yang dimiliki dan tergugah untuk mengubahnya. Lansia juga menyadari bahwa kesehatan psikologis akan memengaruhi kesehatan fisik dan pad aakhirnya memengaruhi perilaku sehari-hari. Kesehatan psikologis dapat ditingkatkan melalui kegiatan sehari-hari, tertutama dengan cara bersemangat (antusias), optimis dan bersyukur.

\section{DAFTAR PUSTAKA}

[1]. Wahyudi, M.Z. (2021). Mewaspadai Lonjakan Jumlah Penduduk Lanjut Usia [Online]. Dikutip dari https://www.kompas.id/baca/kesehatan/2021/06/10/waspadailonjakan-jumlah-penduduk-lanjut-usia/ [diakses 5 Agustus 2021]

[2]. Setyorini, Y (2021). Sensus Penduduk tahun 2020: Hasil dan Analisa (Part III) [Online]. Dikutip dari https://www.indonesiare.co.id/id/article/sensus-penduduk-2020hasil-dan-analisa-part-iii [Diakses 5 Agustus 2021]

[3]. Mufarida (2021). Kemenkes : Jumlah Lansia di Indonesia Hampir Sama dengan Lansia Negara G20 [Online]. Dkutip dar https://nasional.sindonews.com/read/324370/15/kemenkes-jumlahlansia-di-indonesia-hampir-sama-dengan-lansia-negara-g201612422163 [Diakses 6 Agustus 2021].

[4]. TNP2K (2020). Vulnerability of the Elderly Amid the Covid-19 Outbreak: Efforts to Ensure Comprehensive Social Protection to 
Address Vulnerability [Online]. Dikutip dari http://tnp2k.go.id/articles/vulnerability-of-the-elderly-amid-thecovid-19-outbreak:-efforts-to-ensure-comprehensive-socialprotection-to-address-vulnerability [Diakses 6 Agustus 2021].

[5]. Bappenas (2020). Tingkat Harapan Hidup dan Perasaan Bahagia Lansia Malah Meningkat Semasa Covid-19 [Online]. Dikutip dari https://www.bappenas.go.id/id/berita-dan-siaran-pers/tingkatharapan-hidup-dan-perasaan-bahagia-lansia-malah-meningkatsemasa-covid-19/_[Diakses 6 Agustus 2021].

[6]. Komazawa, Suriastini, Mulyanto, Wijayanti, Maliki \& Kharisma, (2021). Lanjut Usia dan Covid-19 di Indonesia [Online]. https://surveymeter.org/id/Lanjut-Usia-dan-COVID-19-di-Indonesia [Diakses 6 Agustus 2021].

[7]. Connors, M. H., \& Halligan, P. W. (2015). A cognitive account of belief: a tentative road map. Frontiers in Psychology, 5.doi:10.3389/fpsyg. 2014.01588

[8]. Jopp, D. S., \& Schmitt, M. (2010). Dealing with negative life events: differential effects of personal resources, coping strategies, and control beliefs. European Journal of Ageing, 7(3), 167180.doi:10.1007/s10433-010-0160-6

[9]. Li, C., Wang, S., Zhao, Y., Kong, F., \& Li, J. (2017). The Freedom to Pursue Happiness: Belief in Free Will Predicts Life Satisfaction and Positive Affect among Chinese Adolescents. Frontiers in Psychology, 7.doi:10.3389/fpsyg.2016.02027

[10]. Supratiknya, A. (2011). Merancang Program dan Modul. Yogyakarta: Universitas Sanata Dharma.

[11]. Sarkhel, S., Singh, O. P., \& Arora, M. (2020). Clinical practice guidelines for psychoeducation in psychiatric disorders general principles of psychoeducation. Indian journal of psychiatry, 62 (Suppl 2), S319.

[12]. Brown, N. W. (2004). Psychoeducational Groups: Process and Practice. Routledge.

[13]. Riasnugrahani, M. (2021). Surviving and Thriving in Times of Crisis: The Power of Optimism, Adaptability and Positive Religious Coping. In Community Service in the Midst of the Covid-19, 70-74. Novateur Publication, India.

[14]. Kirkpatrick, D. \& Kirkpatrick, P. (2006). Evaluating Training Programs. 3rd Edn, Berrett-Koehler Publishers, San Francisco, CA.

[15]. Brown, N. W. (2018). Psychoeducational Groups: Process and Practice. Routledge.

[16]. Hébert, C., Dagenais, C., Mc Sween-Cadieux, E., \& Ridde, V. (2020). Video as a public health knowledge transfer tool in Burkina Faso: A mixed evaluation comparing three narrative genres. PLoS neglected tropical diseases, 14(6), e0008305. https://doi.org/10.1371/journal.pntd.0008305

[17]. Brame C. J. (2016). Effective Educational Videos: Principles and Guidelines for Maximizing Student Learning from Video Content. CBE life sciences education, 15(4), es6. https://doi.org/10.1187/cbe.16-03-0125

Buizza, C., Candini, V., Ferrari, C., Ghilardi, A., Saviotti, F. M., Turrina, C., Nobili, G., Sabaudo, M., \& de Girolamo, G. (2019). The Long-Term Effectiveness of Psychoeducation for Bipolar Disorders in Mental Health Services. A 4-Year Follow-Up Study. Frontiers in psychiatry, 10, 873.

https://doi.org/10.3389/fpsyt.2019.00873 